\title{
THE ETHICAL VALUE OF NARRATIVE REPRESENTATION
}

\section{Rafe McGregor}

The purpose of this paper is to defend a deflationary account of the ethical value of narrative representation. In $\S \S 1-2$ I demonstrate that there is a necessary relation between narrative representation and ethical value, but not between narrative representation and moral value. Ethical is conceived in terms of moral as opposed to amoral and moral in terms of moral as opposed to immoral and the essential value of narrative representation is restricted to the former. Recently, both theorists involved in the ethical turn in criticism and analytic philosophers have erred in conflating these two distinct kinds of value. In $\S \S 3-5$ I defend my deflationary view against three attempts to elevate the ethical value of narrative representation to moral value: Martha Nussbaum's theory of realist novels, Noël Carroll's virtue wheels, and Geoffrey Galt Harpham's closural moral order.

\section{Narrative \& Non-Narrative Representation}

My starting point is to take "narrative" and "story" as synonymous. Representations of real and fictional sequences of events can be communicated in narrative and non-narrative form by a variety of means, including the written and spoken word and still and moving images. I shall distinguish between narrative and non-narrative representations, but not between narratives that represent real and fictional events or between linguistic and visual narratives. ${ }^{1}$ A minimal narrative is the product of an agent that represents:

\footnotetext{
${ }^{1}$ My preference is to distinguish representations of real sequences of events from representations of fictional sequences of events in terms of the different role played by the imagination in the respective engagement with each. Derek Matravers has recently questioned this distinction, first claiming that there is no relevant difference between the employment of the imagination in factual and fictional representations, and then questioning the
} 
(a) one or more agents ${ }^{2}$ and

(b) two or more events which are

(c) connected.

Gregory Currie begins his discussion of narrativity by noting that all representations are created rather than found and therefore the product of a process of intentional shaping. ${ }^{3} \mathrm{~A}$ consequence of this intentionality is that there are two perspectives that can be adopted towards representations, the external and internal:

Adopting the external perspective, we see a vehicle, something that represents a sequence of events in virtue of the activity of an agent we call the author. Adopting the internal perspective, we examine the world of the story as if it were actual $[\ldots]{ }^{4}$

Narrativity is gradational rather than categorical, i.e. admits of degrees. The manner in which (a) and (b) contribute to narrativity is straightforward, but (c) has been subject to much debate. Peter Lamarque takes the broadest view of the requisite connection, claiming that: there must be some more or less loose, albeit non-logical, relation between the events. Crucially, there is a temporal dimension in narrative, not just in the sense that component sentences are tensed but also in that there must be a temporal relation between the events, even if just that of simultaneity. ${ }^{5}$

I shall accept this loose temporal connection for minimal narratives, the consequence of which is that the following meets the criteria for a minimal narrative: "Katy kicked the stone

role of the imagination in engaging with representations at all (Fiction and Narrative [Oxford: Oxford University Press, 2014]). As my aim is to delineate an uncontroversial characterisation of narrative, I shall neither contribute to this debate nor employ the imagination in my elucidation of narrative representation. ${ }^{2}$ Peter Goldie notes the possibility of narratives with no human characters, but excludes these from his discussion (The Mess Inside: Narrative, Emotion, and the Mind [Oxford: Oxford University Press, 2012], 19 fn.20). I shall not stipulate that the agents must be human, merely that they are capable of intentional action, such as the anthropomorphised rabbits in Richard Adams' Watership Down and the false Maria robot in Fritz Lang's Metropolis.

${ }^{3}$ Gregory Currie, Narratives \& Narrators: A Philosophy of Stories (Oxford: Oxford University Press, 2010), 2.

${ }^{4}$ Currie, Narratives \& Narrators, 49.

${ }^{5}$ Peter Lamarque, The Opacity of Narrative (London: Rowman \& Littlefield International, 2014), 52. 
and missed her bus." As such, Currie is correct to claim that it is not the concept "narrative" that is philosophically interesting, but 'the concept thing high in narrativity. ${ }^{6}$

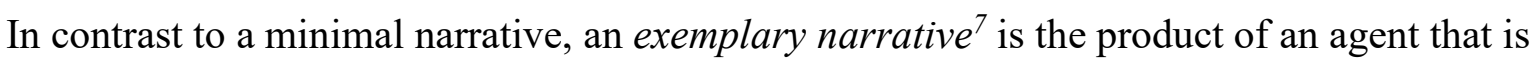
high in narrativity in virtue of representing:

(i) one or more agents and

(ii) two or more events which are

(iii) causally connected,

(iv) thematically unified, and

(v) conclude.

Regarding (iii), Noël Carroll proposes the following connection: 'the earlier events in the sequence are at least causally necessary conditions for the causation of later events and/or states of affairs (or are contributions thereto). ${ }^{8}$ I shall accept that non-minimal narratives have a causal connection between events and that exemplary narratives have a causal connection which is so strong as to contribute to the thematic unity of the narrative. Currie defines thematic unity as follows:

unity is provided by a focus on some common thread in the activity of particular persons in particular connected circumstances, though narratives often do have, in addition, general thematic unity in that we are invited to generalize from the case in question. $^{9}$

Carroll divides narratives into two broad categories: episodic narratives, consisting of smaller stories where causal linkage is weak and frequently achieved by means of a recurring protagonist; and unified narratives, where causal linkage is high and there is a smooth

\footnotetext{
${ }^{6}$ Currie, Narratives \& Narrators, 34.

${ }^{7}$ The term is from Currie; see: Narratives \& Narrators, 35.

${ }^{8}$ Noël Carroll, Beyond Aesthetics: Philosophical Essays (New York: Cambridge University Press, 2001$), 126$.

${ }^{9}$ Currie, Narratives \& Narrators, 39.
} 
transition from beginning to middle to end. ${ }^{10}$ The significance of thematic unity restricts exemplary narratives to the latter.

In his taxonomy of historical representations, Hayden White identifies the absence of closure as characterising a text as a chronicle rather than a narrative: a chronicle merely terminates in medias res, leaving the reader to impose his or her own meaning upon the sequence of events represented. ${ }^{11}$ Carroll describes the phenomenon as 'the almost palpable sensation that the story has finished-up at exactly the right spot. ${ }^{12}$ In the taxonomy I am establishing, chronicles meet the criteria for minimal narratives, but not exemplary narratives. White's insistence on the importance of closure might be considered overly-demanding, however, and Carroll claims that soap operas and national histories are examples of exemplary narratives without closure. ${ }^{13}$ Soap operas are indeed high in narrativity, but they lack thematic unity and are episodic in nature. Every soap opera has several stories running parallel, usually involving characters who live in the same place, and the narrativity within these subnarratives may be high despite the absence of an overarching, thematic connection. National histories are similar in that they take a place as their primary focus, involve a large number of characters and sub-narratives, and are typically lacking in an overarching theme. On the basis that they are at best borderline cases, I shall exclude both soap operas and national histories from the category of exemplary narratives. Given (iii) to (v) above, exemplary narratives can be distinguished from lists, annals, chronicles, and diaries. Paradigmatic examples include: the Bayeux Tapestry, William H. Prescott's History of the Conquest of

\footnotetext{
${ }^{10}$ Carroll, Minerva's Night Out: Philosophy, Pop Culture, and Moving Pictures (Malden, MA: WileyBlackwell, 2013), 123.

${ }^{11}$ Hayden White, "The Value of Narrativity in the Representation of Reality," Critical Inquiry 7 (1980), 5-27: 21-23.

${ }^{12}$ Carroll, Minerva's Night Out, 123.

${ }^{13}$ Carroll, Art in Three Dimensions (Oxford: Oxford University Press, 2010 [2012]), 355-356.
} 
Peru, Joseph Conrad's Heart of Darkness, Leni Riefenstahl's Triumph of the Will, Orson

Welles' Citizen Kane, and Art Spiegelman's Maus.

\section{Ethical Value \& Narrative Representation}

Given my definitions in $\S 1$, all narratives are concerned with agency in that they represent a minimum of a single agent and two events. The combination of agency and events places narratives in the ethical sphere as all action (and inaction) is subject to ethical appraisal. There is thus a necessary relation between narrative representation and ethical value. There are at least four ways of unpacking this relation:

(a) In virtue of their narrativity, narrative representations can be evaluated ethically.

(b) In virtue of their narrativity, narrative representations can provide illumination when evaluated ethically.

(c) In virtue of their narrativity, narrative representations should be evaluated ethically.

(d) The value of narrative representations qua narrative representation is ethical value.

If the combination of agency and events entails an ethical dimension to narrative representation then (a) is obviously - but also trivially - true. Similarly, (b) is obviously and trivially true of some narrative representations, but not others (especially minimal narratives, as I demonstrate below). The claim in (d), that the value of narrative qua narrative (which is often conceived of as aesthetic value) is ethical value is the thesis that ethical value is partly or wholly constitutive of narrative value. I make no such commitment in this paper and I shall therefore defend (c), the claim that narrative representations not only can, but should, be 
evaluated ethically in virtue of their narrativity. This claim is motivated by the ethical essence of narrative representation identified above, the consequence of which is that the ethical dimension cannot be ignored in narrative evaluation. ${ }^{14}$ My understanding of the necessary relation between narrative representation and ethical value is thus that:

$\left(\mathrm{EN}^{\mathrm{NR}}\right) \quad$ The engagement with a narrative representation qua narrative representation is incomplete without ethical evaluation.

I noted that narrative representation entails dual agency in $\S 1$ : even a minimal narrative is the product of an agent in which (at least) one agent is represented. I quoted Currie's identification of the internal perspective as examining the world of the story as if it were actual. Consider the following pair of minimal narratives:

(i) Katy kicked the stone and missed her bus.

(ii) Katy kicked the dog and ran away.

Adopting the internal perspective, one evaluates Katy's actions in both cases. In the absence of further information, (i) is ethically permissible and (ii) ethically prohibited. Currie describes the external perspective as seeing a vehicle, something that represents a sequence of events in virtue of the activity of an agent we call the author. In adopting the external perspective it is not the agency of the agent in the narrative, but of the producer of the narrative - the author - that is judged. ${ }^{15}$ (ii) could be represented for the following purposes:

(A) as an example of shameful behaviour;

(B) as an example of admirable behaviour.

\footnotetext{
${ }^{14}$ I offer evidence of the ethical essence of exemplary narratives in my discussion of plot in $\S 5$.

${ }^{15}$ For the purposes of this paper, I shall use "author" to describe the producer of a narrative regardless of the representational medium employed. Some narrative representations feature a narrator who is distinct from the author, but I shall not discuss the complexities of this distinction (see: Currie, Narratives \& Narrators, 65-69). I shall also use "audience" to describe the people who engage with a narrative representation regardless of the medium in which that representation is experienced.
} 
From the internal perspective, Katy's action is evaluated as unethical in both contexts (A) and (B); from the external perspective, the author is evaluated as ethical if he is criticising Katy's action, i.e. in (A); but unethical if he is demonstrating how clever she was, e.g. in being able to inflict harm on the dog without being bitten, i.e. in (B). The problem with (i) and (ii) is that the narratives are so minimal, communicating so little information, that there is barely any evidence to make an ethical evaluation of the character and none at all for an ethical evaluation of the author. Both examples remain the product of an agent for which $\mathrm{EN}^{\mathrm{NR}}$ is true, but they show that the ethical evaluation of narratives is neither necessarily illuminating nor always possible from the external perspective.

In $§ 1$ I identified the difference between minimal narratives and exemplary narratives as causal relations, thematic unity, and closure. These three features combine to create a perspective or framework that is absent in minimal narratives. Exemplary narratives are essentially perspectival, as Goldie makes clear in his definition:

a representation of those events which is shaped, organized, and coloured, presenting those events, and the people involved in them, from a certain perspective or perspectives, and thereby giving narrative structure - coherence, meaningfulness, and evaluative and emotional import - to what is related. ${ }^{16}$

Lamarque refers to this perspectival nature as opacity:

narratives are "opaque" somewhat as paintings are opaque. ${ }^{17}$ They have the same kind of intentionality, not just as products of intentions, but also, in different ways and to different degrees, through expressing thoughts or a point of view on what they represent. This seems to be true of all narratives, not just those of literary fiction. ${ }^{18}$

\footnotetext{
${ }^{16}$ Peter Goldie, The Mess Inside: Narrative, Emotion, and the Mind (Oxford: Oxford University Press, 2012), 2.

${ }^{17}$ The opacity of paintings is that, unlike photographs, 'they do not represent simply in virtue of standing in a causal relation to their subjects' (Lamarque, The Opacity of Narrative, 9).

${ }^{18}$ Lamarque, The Opacity of Narrative, 9.
} 
Similarly, Currie identifies a framework as 'a preferred set of cognitive, evaluative, and emotional responses to the story. ${ }^{19}$ He notes that there are no set of explicit instructions, but that the framework is expressed in the representation of the sequence of events. From this framework Currie proceeds to

the standard mode of engagement with narrative. Narratives, because they serve as expressive of the points of view of their narrators, create in our minds the image of a persona with that point of view, thereby prompting us to imitate salient aspects of it notably evaluative attitudes and emotional responses. In taking on those responses, we thereby come to adopt, wholly or in part, the framework canonical for that work. ${ }^{20}$ The standard mode of engagement is thus the acceptance, by audiences, of the framework that the author invites one to adopt.

It is this framework - the preferred set of cognitive, evaluative, and emotional responses that produces a more complex relation between narrative representation and ethical value in the case of exemplary narratives. In contrast to minimal narratives, the necessary relation between narrative representation and ethical value in exemplary narratives is twofold:

$\left(\mathrm{EN}^{\mathrm{EX}}\right) \quad$ The engagement with an exemplary narrative qua narrative is incomplete without a dual ethical evaluation, from both the internal and external perspectives.

The History of the Conquest of Peru and Citizen Kane therefore invite the following ethical evaluations:

(1) the agency of the characters represented in the narrative, presented as they are by the author within a particular framework; e.g., the agency of Francisco Pizarro or Charles Foster Kane.

\footnotetext{
${ }^{19}$ Currie, Narratives \& Narrators, 86.

${ }^{20}$ Currie, Narratives \& Narrators, 106.
} 
(2) the agency of the author in telling the story, which includes the decision to present the characters in the narrative within the particular framework in which they are represented; e.g., the agency of Prescott or Welles.

Both the actions of the characters in the story and action of the author in telling the story are subject to ethical appraisal and different authors can provide different frameworks for the same characters and events. In Triumph of the Will, e.g., Riefenstahl invites one to regard Hitler as a messianic saviour who descends from the heavens to lead the German people to glory. In contrast, Oliver Hirschbiegel invites one to regard Hitler as an evil megalomaniac who sacrifices millions of people - including the German nation - for his selfaggrandisement in Downfall. If one rejects the standard mode of engagement for Triumph of the Will - Hitler as heroic - in adopting the internal perspective, then one will make a negative judgement of Riefenstahl in creating that framework in adopting the external perspective. $^{21}$

When discussing closure as a criterion of exemplary narratives in $§ 1$, I mentioned White, who maintains that narrative closure is a resolution that is presented by the author as either moral or immoral. ${ }^{22}$ When history is represented in a narrative rather than non-narrative form:

The demand for closure $[\ldots]$ is a demand [...] for moral meaning, a demand that sequences of real events be assessed as to their significance as elements of a moral drama. $^{23}$

In the terminology I am employing, White is claiming that the standard mode of engagement with (historical exemplary) narratives requires the adoption of an internal perspective that prioritises ethical evaluation. The necessary relation he proposes is thus similar to mine, but

\footnotetext{
${ }^{21}$ Riefenstahl denied the framework I have described here post-war, which is hardly surprising. For an unsurpassed philosophical discussion of the film see: Mary Devereaux, "Beauty and evil: the case of Leni Riefenstahl's Triumph of the Will," in J. Levinson, ed., Aesthetics and ethics, 227-256.

${ }^{22}$ White, "The Value of Narrativity," 23.

${ }^{23}$ White, "The Value of Narrativity," 24.
} 
narrower and stronger. My claim is that all narrative representations require the adoption of an internal perspective that involves ethical evaluation on the basis of the necessary ethical dimension of narrative representation. The greater complexity of the necessary relation between exemplary narratives and ethical evaluation on the one hand and minimal narratives and ethical evaluation on the other hand creates the need for a two-part thesis:

$\left(\mathrm{T}^{\mathrm{NR}}\right)$ Narrative representations are essentially ethical in virtue of their combination of agency and events.

$\left(\mathrm{T}^{\mathrm{EX}}\right)$ Exemplary narratives are essentially ethical in virtue of both the combination of agency and events represented and the agency of the author in adopting the framework particular to the narrative.

In other words, narrative representation necessarily invites ethical evaluation in the adoption of the internal perspective and exemplary narrative representation necessarily invites a dual ethical evaluation, in the adoption of both the internal and external perspectives.

This is neither a controversial nor remarkable claim and would perhaps not even be interesting had it not served as a springboard for erroneous conclusions about the relationship between narrative representation and ethical value. I mentioned the following distinction in my abstract, which I have been employing heretofore and shall continue to employ (unless quoting directly):

(I) Ethical as opposed to a-ethical or amoral, i.e. a positive, negative, or ambiguous evaluation of agency or character; and

(II) Moral as opposed to immoral or unethical, i.e. a positive evaluation of agency or character. ${ }^{24}$

\footnotetext{
${ }^{24}$ The difference is usually conceived in terms of "ethics" as a concern with social values and/or the good life and "morality" as a concern with judgement and/or the principles of right conduct. The locus classicus of this distinction is Hegel's critique of Kant's Moralität (morality) in terms of Sittlichkeit (ethical life) in Phenomenology of Spirit and Elements of Philosophy of Right. It is sometimes articulated in terms of ethics as
} 
Returning to the pair of examples above, both Triumph of the Will and Downfall have ethical value, but only Downfall has moral value. My thesis, as articulated in $\mathrm{T}^{\mathrm{NR}}$ and $\mathrm{T}^{\mathrm{EX}}$, is that narrative representation is essentially ethical in virtue of its narrativity. The erroneous conclusion to draw is that every narrative representation is essentially moral, i.e. subject to a positive ethical evaluation in virtue of its narrativity. In order to avoid conflation with a distinction that can at times be subtle, I shall revise my two-part thesis as follows:

$\left(\mathrm{TR}^{\mathrm{NR}}\right) \quad$ Narrative representations are essentially ethical, but not essentially moral, in virtue of their combination of agency and events.

$\left(\mathrm{TR}^{\mathrm{EX}}\right) \quad$ Exemplary narratives are essentially ethical, but not essentially moral, in virtue of both the combination of agency and events represented and the agency of the author in adopting the framework particular to the narrative.

The arguments that narrative representations are essentially moral focus exclusively on exemplary narratives and I shall follow suit. In the remainder of this paper I defend my deflationary account of the ethical value of exemplary narratives, $\mathrm{TR}^{\mathrm{EX}}$, against three inflationary accounts - from Nussbaum, Carroll, and Harpham respectively.

\section{The Moral Value of Novels}

The elevation of the ethical value of narrative representation to moral value has primarily focused on fictional narratives, especially - although not exclusively - literary fictions, usually understood as those fictions that are either judged as artistically or aesthetically valuable. Patrick Fessenbecker describes the 'ethical turn' at the end of the twentieth century

descriptive and morality as normative, but this is an over-simplification - particularly when applied to the evaluation of narrative representations. The distinction has been embraced by critical theory and developed by Jürgen Habermas, who contrasts moral discourse with ethical discourse in Justification and Application and The Inclusion of the Other. In analytic philosophy, Bernard Williams adopted the distinction in Ethics and the Limits of Philosophy. 
as involving a confluence of three traditions: the neo-Aristotelian, exemplified by Nussbaum; the challenge to scientistic epistemology, exemplified by Richard Rorty; and Levinasian poststructuralism, exemplified by Jacques Derrida. ${ }^{25}$ What each of these disparate strands holds in common is a belief that the literary experience, the experience of engaging with a literary work qua literature (however that is conceived in the respective traditions) is in some way essentially moral. Within the ethical turn, more attention has been paid to literary narratives than lyric poetry and Rorty and Nussbaum focus on the narrative category of novels. ${ }^{26}$ Nussbaum narrows her focus even further, to the genre of 'realist AngloAmerican' ${ }^{27}$ and 'realist social' ${ }^{28}$ novels, of which the works of Charles Dickens, Henry James, Marcel Proust, and Richard Wright are paradigmatic. I shall hereafter refer to this genre of exemplary narratives as realist novels. Nussbaum's approach takes the unity of literary form and literary content as its starting point. As I am sympathetic to the view that there is a particularly intimate relationship between form and content in literature, I shall accept the inseparability relation without probing its precise nature, agreeing that form and content cannot be separated in the experience of a work of literature qua literature, although they can and are separated for critical and analytical purposes. ${ }^{29}$ Commentators have identified three ways in which Nussbaum binds form-content inseparability to moral value literary content, literary form, and literary imagination - and I shall consider each in turn. ${ }^{30}$

\footnotetext{
${ }^{25}$ Patrick Fessenbecker, "In Defense of Paraphrase,” New Literary History 44 (2013), 117-139: 118.

${ }^{26}$ Richard Rorty's nuanced contribution to the ethical turn is set out in: Contingency, irony, and solidarity (New York: Cambridge University Press, 1989).

${ }^{27}$ Martha Nussbaum, Love's Knowledge: Essays on Philosophy and Literature (New York: Oxford University Press, 1990 [1992]), 10.

28 Nussbaum, Love's Knowledge, 87.

29 There are various conceptions of form-content unity, which include the following relations: identity, indistinguishability, constitution, inseparability, and irreducibility. Nussbaum is unclear as to the precise relation envisaged. Due to the terminology employed in the quote immediately below I have characterised the relation as inseparability, but the same quote could also be conceived as a constitution relation, e.g. that form (partly) constitutes content.

${ }^{30}$ See, e.g., respectively: Patrick Gardiner, "Professor Nussbaum on The Golden Bowl," New Literary History 15 (1983), 179-184; Richard Eldridge, “"Reading for Life': Martha C. Nussbaum on Philosophy and Literature," Arion 2 (1992), 187-197; and Cora Diamond, "Martha Nussbaum and the Need for Novels," Philosophical Investigations 16 (1993), 128-153.
} 
According to Nussbaum: 'Literary form is not separable from philosophical content, but is, itself, a part of content - an integral part, then, of the search for and of the statement of truth. ${ }^{31}$ A consequence of inseparability is that content cannot be paraphrased without loss of identity and, as a result, certain truths can only be conveyed in narrative form such that there is a unique kind of non-propositional moral knowledge communicated by realist novels. Realist novels are particularly suited to the Aristotelian conception of moral value because of their structural complexity, open-endedness, and concern with the ordinary and the everyday. ${ }^{32}$ The standard mode of engagement with these novels extends life horizontally by broadening the reader's experience of people, places, and events, and vertically by the precision and richness of their representations. ${ }^{33}$ Nussbaum extends the moral value of realist novels to the political sphere, claiming that they promote liberal democracy. The moral and political value of reading, e.g., Hard Times is that the novel 'makes us acknowledge the equal humanity of members of social classes other than our own'. ${ }^{34}$ Dickens' framework combines narrative form with moral content such that one cannot adopt the standard mode of engagement without accepting that the factory workers are fully human. Hard Times thus embodies a liberal democratic vision in its framework, which is enacted by the novel's form. ${ }^{35}$ Realist novels promote compassion as well as egalitarianism because 'concern for the disadvantaged is built into the structure of the literary experience'. ${ }^{36}$ The moral content of realist novels cannot be separated from the narrative representation without loss of identity and the moral evaluation of a novel therefore requires that the moral content be judged in the narrative form in which it is presented in the novel rather than in a paraphrased (or otherwisealtered) form. Moral value is not only relevant to the literary value of Dickens' works, but

\footnotetext{
${ }^{31}$ Nussbaum, Love's Knowledge, 3.

${ }^{32}$ Nussbaum, Love's Knowledge, 46-47. These points and the relationship between literature and life mentioned below are reiterated in: Poetic Justice: The Literary Imagination and Public Life (Boston: Beacon Press, 1995).

${ }^{33}$ Nussbaum, Love's Knowledge, 48.

${ }^{34}$ Nussbaum, Poetic Justice, 34.

${ }^{35}$ Nussbaum, Poetic Justice, 36.

${ }^{36}$ Nussbaum, Poetic Justice, 87.
} 
essential, because the novels cannot be read qua literature without accepting the morality promoted..$^{37}$

In the terms I set out in $\S 2$, Nussbaum advances the following claim:

$\left(\mathrm{MN}^{\mathrm{RN}}\right) \quad$ Realist novels are essentially moral in virtue of both the combination of agency and events represented and the agency of the author in adopting the framework particular to the novel.

In defence of $\mathrm{MN}^{\mathrm{RN}}$, Nussbaum argues that novels with immoral frameworks do not constitute counter-examples to her position. 'Literature has great seductive power: it can get us to sympathize with class privilege, the oppression of women, war and pillage, and [...] hideous racism. ${ }^{38}$ Her point is that in the category she has selected (the novels of Dickens, James, Proust, and Wright) the narrative form is part and parcel of the moral value and this thesis is unaffected by the existence of other categories (e.g., the surrealist novels of Henry Miller and Louis-Ferdinand Céline), where the narrative form is part and parcel of the negative (or ambiguous) ethical value. The problem with this strategy is that it reveals Nussbaum's thesis as at best philosophically uninteresting and at worst tautologous. The novels of Dickens, James, Proust, and Wright have been selected precisely for their moral value in the first instance and $\mathrm{MN}^{\mathrm{RN}}$ therefore collapses into:

$\left(\mathrm{MN}^{\mathrm{MN}}\right) \quad$ Moral novels are essentially moral in virtue of both the combination of agency and events represented and the agency of the author in adopting the framework particular to the novel.

$\mathrm{MN}^{\mathrm{MN}}$ is not only compatible with my thesis, $\mathrm{TR}^{\mathrm{EX}}$, but fails to elevate the ethical value of narrative representation to moral value. All exemplary narratives are essentially ethical and within the broad category of exemplary narratives sub-categories can be selected according to

\footnotetext{
${ }^{37}$ Nussbaum, "Exactly and Responsibly," 360.

${ }^{38}$ Nussbaum, "Exactly and Responsibly," 355.
} 
their ethical valence, e.g. realist novels (moral value) and surrealist novels (negative ethical value).

The second approach to Nussbaum's theory has focused on the substantive value of literary form, which is also expressed in terms of the literary experience as essentially moral. Terry Eagleton offers a precise explanation of this conception of realist novels in the following two passages:

(a) The classical realist novel is [...] a moral practice in its very structure, shifting as it does from one centre of consciousness to another to constitute a complex whole. Literature can therefore be seen as a moral project even before it has come to utter a moral sentiment. ${ }^{39}$

(b) the exhausting, exhilarating process of tracking the microscopic twists and turns of meaning in The Ambassadors or The Golden Bowl is itself a moral experience, rather as the inordinate length of the Proustian sentence, its capacity to propel itself through any number of intricate sub-clauses and around any number of hairpin syntactical bends without losing its steady semantic thrust, is a stylistic performance with intimate relevance to questions of moral value. ${ }^{40}$

In contrast to the focus on the moral value of literary content, which is characteristic of literary aesthetics, the focus on the moral value of literary form is characteristic of literary theory and tends to follow the theoretical approach in arguing on a case-by-case rather than categorical basis.

\footnotetext{
${ }^{39}$ Terry Eagleton, The Event of Literature (London: Yale University Press, 2012), 60.

${ }^{40}$ Eagleton, The Event of Literature, 47.
} 
The shifting structural complexity of realist novels is mentioned by both Eagleton and Nussbaum, ${ }^{41}$ but the feature is by no means restricted to the genre. In his L.A. Quartet (The Black Dahlia, The Big Nowhere, L.A. Confidential, and White Jazz), James Ellroy employs parallel points of view and labyrinthine storylines to present a dark and disturbing vision of an oppressive, corrupt, racist, and homophobic mid-century Los Angeles. The literary form of the Quartet becomes successively richer and more complex as the various protagonists become progressively more debased and irresponsible. The detective duo of The Black Dahlia, Bucky Bleichert and Lee Blanchard, are choirboys in comparison with the only three central characters that survive the rigours of the Quartet - David Klein, Edmund Exley, and Dudley Smith. The combination of formal innovation and downward moral spiral is most evident in White Jazz, where Ellroy uses the stream of consciousness style to original and subtle effect, creating an engrossing and compelling framework in which Klein is portrayed as worthy of admiration despite his many substantial moral flaws. Ellroy's series may not constitute an immoral practice in Eagleton's terms, but it is certainly a morally ambiguous practice. The problem for Nussbaum's claims about the moral value of literary form is that it appears as if similar narrative means can be employed to disparate ethical ends. Shifting structural complexity, microscopic twists and turns of meaning, inordinately long sentences, and stream of consciousness could all have different ethical valence if used by, e.g., either Henry James or James Ellroy. There is thus no necessary relation between literary form and moral value and Eagleton explicitly avoids making any such commitment, defining the moral dimension of literature as 'the realm of human meanings, values and qualities'. ${ }^{42}$

Eagleton is also dismissive of the third way in which Nussbaum's claims about the moral value of realist novels have been defended, by recourse to the literary imagination.

\footnotetext{
${ }^{41}$ See, e.g., Nussbaum, Love's Knowledge, 139-142.

${ }^{42}$ Eagleton, The Event of Literature, 59.
} 
Nussbaum maintains that the imaginative experience of reading realist novels qua literature promotes empathy and attention to the historical and social contexts of moral judgement. ${ }^{43}$ She associates literary content with responsiveness to moral particulars and literary form with the relation between particulars and universals that is constitutive of moral judgement. The idea is that if form and content are inseparable, then the responsiveness to particulars cannot be isolated from the play back and forth between particular and universal, in consequence of which the literary imagination opens up possibilities for moral deliberation and action. The exercise of the literary imagination is therefore a moral exercise. Eagleton does not mention Nussbaum, citing instead the tradition from Shelley to Iris Murdoch, but his critique is nonetheless applicable. He claims that there is no necessary relation between the literary imagination and the moral - as opposed to ethical - imagination, noting that the imagination can be both creative and destructive and put to moral and immoral use. Eagleton's response is both concise and compelling: 'It was not that the Nazis could not imagine how those they slaughtered were feeling. It is that they did not care. ${ }^{44}$ All three versions of Nussbaum's argument for the moral value of realist novels are thus revealed to suffer from the same flaw, the failure to demonstrate a relation between exemplary narratives and moral rather than ethical value. Simply put: literary content, literary form, and the literary imagination can all vary in their ethical valence.

\section{The Virtue of Narrative Representation}

Although Carroll is not usually identified as belonging to the ethical turn, he has in fact written numerous papers on the moral value of art and the link between artistic and moral

\footnotetext{
${ }^{43}$ Nussbaum, Poetic Justice, 115.

${ }^{44}$ Eagleton, The Event of Literature, 62.
} 
value is one of the central themes of Art in Three Dimensions. ${ }^{45}$ With regard to the moral value of narrative art, Carroll has a rigorous and sophisticated approach that begins at a similar point to that which I established in $§ 2:$ 'artworks that are narratives of human affairs are generally the kind of thing it makes sense both to talk about in ethical terms and to assess morally. ${ }^{46}$ Carroll maintains that there is a necessary relation between narrative representation and moral judgement. ${ }^{47}$ The engagement with a narrative necessarily involves the mobilisation of the knowledge and emotions of readers or audiences, which includes the activation of moral beliefs and emotions, and thus necessarily exercises the moral powers of those engaging with the narrative. ${ }^{48}$ He regards the emotions as the basis of this link between work and response and the capacity of narrative representation to stimulate the moral emotions of audiences is crucial to his thesis. As with Nussbaum on form-content inseparability, I shall accept this claim without analysing the details of his position. ${ }^{49}$ Carroll maintains that narrative artworks can enrich the moral understanding of audiences, an approach he calls 'the clarificationist view' ${ }^{50}$ He is careful to ward off the objection that the knowledge yielded by artistic narrative representations is banal or platitudinous, maintaining that the refinement of virtue concepts is cognitively valuable because it cultivates greater discrimination and thereby enhances understanding. ${ }^{51}$ Carroll articulates the value of this

\footnotetext{
${ }^{45}$ Carroll's own ethical turn began in 1996, with the following two papers: "Moderate Moralism," British Journal of Aesthetics 36 (1996), 223-238; and "Moral Realism in the Age of Postmodernism," in G. Hoffman \& A. Hornung (eds.), The Moral Turn of Postmodernism (Heidelberg: Universitätsverlag C. Winter, 1996), 87-96. His continued interest in the subject is evident in his latest book, Minerva's Night Out.

${ }^{46}$ Carroll, "Art, narrative, and moral understanding," in J. Levinson (ed.), Aesthetics and Ethics: Essays at the Intersection (New York: Cambridge University Press, 1998), 126-160: 138.

${ }^{47}$ Carroll's conception of this relation is consistent with his view, expressed throughout Art in Three Dimensions and elsewhere, that both moral value and cognitive value are constitutive of artistic value, i.e. that there is a necessary relation between moral value and artistic value and between cognitive value and artistic value.

${ }^{48}$ Carroll, "Art, narrative, and moral understanding," 141.

${ }^{49}$ Unlike Nussbaum on form-content inseparability, however, Carroll has specified the relation between narrative representation and the moral emotions on numerous occasions, most recently in Minerva's Night Out, 85-105 \& Art in Three Dimensions, 373-395.

${ }^{50}$ Carroll, "Art, narrative, and moral understanding," 142.

${ }^{51}$ Carroll, Art in Three Dimensions, 216.
} 
refinement in his description of one of the means by which clarificationism operates, the deployment of a narrative device called a virtue wheel:

A virtue wheel or virtue tableau comprises a studied array of characters who both correspond and contrast with each other along the dimension of a certain virtue or package of virtues - where some of the characters possess the virtue in question, or nearly so, or part of it, while others possess the virtue, but only defectively, or not at all, even to such an extent that their lack of the virtue in question amounts to the vice that corresponds to the virtue. ${ }^{52}$

One of the examples he employs is Dickens' Great Expectations, where the following characters are compared in terms of their virtues as parents: Joe Gargery, Abel Magwitch, Miss Havisham, and Mrs Gargery. ${ }^{53}$ The novel is structured so as to juxtapose these characters, situating each at a different position on the virtue wheel. The correspondence and contrast between the virtues and vices displayed by these characters in their respective roles as parents in the novel provides a sustained exploration of the concept of parenting by the studious variation of similarity and difference. The virtue wheel is part of the narrative framework created by Dickens. In the standard mode of engagement readers accept the framework and respond to the characters in terms of their respective virtues and vices, i.e. positively towards Joe and negatively towards his wife. The practice serves to sharpen reader recognition ability and make explicit the criteria for the application of the relevant concepts, which is of particular use in moral cases, where concepts are typically vague or abstract. ${ }^{54}$ 'In this, such virtue wheels serve the purpose of moral education'. ${ }^{55}$ Virtue wheels in works such as Sophocles' Antigone, the mystery play Mankind, Great Expectations, and E.M.

\footnotetext{
${ }^{52}$ Carroll, Art in Three Dimensions, 217.

${ }^{53}$ Carroll, Art in Three Dimensions, 217.

${ }^{54}$ Carroll, Art in Three Dimensions, 220.

${ }^{55}$ Carroll, Art in Three Dimensions, 220.
} 
Forster's Howards End share the function of conceptual clarification with thought experiments. Carroll is quick to address the charge that virtue wheels serve as nothing more than organisational devices aimed at preserving the coherence and unity of the work. Virtue wheels do serve this purpose, as a formal device that enhances the thematic unity characteristic of exemplary narratives, but they also prompt self-reflection on the part of readers:

Once the reader has begun to contemplate the pertinent virtues and their putative status in a given literary work, it is natural for her or him to reflect on how the characterizations implied by the text apply outside the text. How are we to determine which virtues are true and which are false without considering the application of the relevant concepts outside the text? ${ }^{56}$

The evidence Carroll offers for virtue wheels thus combines the theoretical, a rewarding interpretation of the respective works, with the empirical, the actual reader or audience response in the standard mode of engagement. Drawing on an analysis of art history, Carroll offers further evidence that art has served a didactic purpose across not only time but space: unquestionably, in many of the artistic traditions of Asia, Africa, and Europe, art from time immemorial has served as a means for teaching about and meditating upon virtue and vice, often by example. ${ }^{57}$

Most of Carroll's elucidation is focused on literature, but he extends the existence of virtue wheels to all narrative art, including theatre, film, television, narrative painting, narrative sculpture, and dance. 'The virtue wheel is a structure that we encounter again and again in

\footnotetext{
${ }^{56}$ Carroll, Art in Three Dimensions, 233.

${ }^{57}$ Carroll, Art in Three Dimensions, 225.
} 
artworks, particularly narratives with more than one character. ${ }^{58}$ The virtue wheel is thus part of the framework of certain narrative works of art such that the standard mode of engagement with those works clarifies the concept of the particular virtue represented and thereby produces an increased moral understanding in readers or audiences. Virtue wheels contribute to the high narrativity of exemplary narratives and those exemplary narratives that deploy virtue wheels therefore have moral value in virtue of their narrativity, i.e. virtue wheels evince a necessary relation between narrative representation and moral value.

The problem with the particular link Carroll proposes between narrative representation and moral value is not its weakness, but its strength. A virtue wheel is clearly an element of both narrativity (linked, in particular, to thematic unity) and moral value (the clarification of virtue concepts) in the examples Carroll employs. Consider, however, D.W. Griffiths' prototype 1915 feature film, The Birth of a Nation. The cinematic work is an exemplary narrative in which the Ku Klux Klan are portrayed as heroic defenders of liberty in the former Confederate States during the Reconstruction Era. The narrative deploys a virtue wheel with regard to the concept of racial equality, presenting an especially complex formal structure due to the salience of racial identity to the instantiation of the virtue and vice in individuals, a complexity that is enhanced by the presence of mixed race characters. The virtue wheel includes: Ben Cameron (white, opposes), Flora Cameron (white, opposes), Mammy (black, opposes), Austin Stoneman (white, supports), Silas Lynch (mixed race, supports), and Gus (black, supports). There are various other characters, such as Elsie Stoneman and Lydia Brown, whose attitudes lie in between support and opposition, which is to be expected from a nuanced treatment of a virtue concept. The problem is that the virtue wheel is not virtuous at all because the narrative framework of which it forms a part determines a standard mode of

\footnotetext{
${ }^{58}$ Carroll, Art in Three Dimensions, 223. Carroll seems to be suggesting that the deployment of virtue wheels is not restricted to the category of exemplary narratives I defined in $\S 1$. As the evidence for virtue wheels is strongest in exemplary narratives, I shall not discuss their deployment beyond this category.
} 
engagement which invites admiration for the Camerons and their loyal black servants and contempt for white abolitionists and non-whites who wish to assert their equality. The virtue wheel in The Birth of a Nation would not therefore be an example of clarificationism for Carroll because the presentation of racial equality as a vice works so as to obscure the virtue concept rather than clarify and refine it.

Carroll's argument for virtue wheels is, however, so compelling that it is clear that both types of narrative wheel - those which clarify and those which obscure moral concepts - contribute to the thematic unity, and thus narrativity, of the works in question. For the sake of brevity I shall refer to the latter as vice wheels. The vice wheel in The Birth of a Nation is part of the framework that determines the standard mode of engagement for the film and operates in a similar way to the virtue wheel in Great Expectations, but provides an immoral perspective on racial equality in contrast to the latter's moral perspective on parenting. In $\S 3$ I mentioned Henry Miller and Tropic of Cancer serves equally well here. Miller's semi-autobiographical novel deploys a vice wheel with regard to misogyny, establishing a framework that determines a standard mode of engagement in which Van Norden, who continually refers to women synecdochically by their genitals, is amusing and Fillmore, who marries a woman he has impregnated, is pathetic. Narrative representations that deploy vice as opposed to virtue wheels have immoral value in virtue of their narrativity and the necessary relation is thus between narrative representation and ethical rather than moral value. Although Carroll's argument for the moral value of narrative representation is more rigorous than Nussbaum's, it is also more sweeping: where she restricts her thesis to realist novels, he is clear that virtue wheels appear in a large proportion of exemplary narratives across the various narrative art forms. He fails to account for vice wheels, however, which are counter-examples to the 
proposed necessary relation between narrativity and moral value. ${ }^{59}$ As with Nussbaum, my thesis accommodates the strengths of Carroll's theory - the deployment of virtue wheels in some narrative representations - without erroneously elevating the necessary relation from ethical value to moral value. Exemplary narratives may clarify or obscure moral concepts in virtue of their narrativity and are thus, in my terms, essentially ethical.

\section{Closural Moral Order}

In his defence of the cognitive value of literature, Fessenbecker states that narrative form entails commitment to propositions about agency, intention, and other features of subjectivity - which he summarises as 'the moral-philosophical commitments inherent in narrative form' ${ }^{60}$ In his terminology, therefore, my claim is that narrative form has inherent ethical commitments. Harpham takes this conception a step further, not merely exploring the ethical commitments of narrative form, but reconceptualising narrative representation in ethical terms. His starting point articulates his disillusion with contemporary research:

One of the most obdurate problems in literary theory is narrative form, the study of which seems to have stalled since Aristotle's statement that the plot of tragedy proceeds towards a moment of reversal, followed by recognition, and ending in a dénouement. [...] But the attempt to define further the basic form of narrative has been virtually abandoned, defeated by the apparent shapelessness and singularity of extended narratives. ${ }^{61}$

Harpham seeks to identify the connection - temporal, causal, or thematic - between agency and event and recommends that narrative form be understood in terms of Hume's distinction

\footnotetext{
${ }^{59}$ Vice wheels are potentially doubly problematic for Carroll because they are both moral defects (promoting vice) and cognitive defects (obscuring concepts). See: fn.47.

${ }^{60}$ Fessenbecker, "In Defense of Paraphrase," 121.

${ }^{61}$ Geoffrey Galt Harpham, Shadows of Ethics: Criticism and the Just Society (Durham, NC: Duke University Press, 1999), 35.
} 
between is and ought, or fact and value. Both the distinction and Hume's purpose in describing it have been the subject of extensive debate, which has focused largely on what R.M. Hare refers to as Hume's Law, the proposal that no "ought" can derived from an "is". ${ }^{6}$ Harpham's ultimate aim is to employ the relationship between narrative and ethics to establish a reciprocal relationship between literature and philosophy. He maintains that ethics provides an explanation of narrative representation and that narrative in turn contributes to ethics by crossing the chasm between fact and value. ${ }^{63}$ My interest is neither in the proposed contribution of narrative to ethics nor the more fundamental relation between literature and philosophy, but in Harpham's explanation of narrative form in exclusively ethical terms. ${ }^{64}$ This explanation is made by means of plot.

I deliberately avoided characterising either minimal or exemplary narratives in terms of "plot" in $\S 1$, due to the variety of ways in which the word is employed across the philosophical and theoretical traditions. White claims that narrative form is imposed upon a sequence of events in narrative history ${ }^{65}$ and this imposition is described as follows by Goldie:

This process, which [...] I will call emplotment, is one by which a bare description of events, such as one might find in an annal or chronicle, can be transformed into a narrative, giving coherence, meaningfulness, and evaluative and emotional import to what is narrated. ${ }^{66}$

\footnotetext{
${ }^{62}$ R.M. Hare, Moral Thinking: Its Level, Method, and Point (Oxford: Clarendon, 1981), 16. Hume sets out the distinction in Book III, Part 1, Section (i) of the Treatise. See: David Hume, A Treatise of Human Nature, ed. L.A. Selby-Bigge (Oxford: Clarendon, 1740 [1888]), 469.

${ }^{63}$ Harpham, Shadows of Ethics, 37 \& 43.

${ }^{64}$ I am sceptical of Harpham's conception of narrative's contribution to ethics and although the relation he envisages is reciprocal, each of the two aspects can be considered in isolation.

${ }^{65}$ White, "The Value of Narrativity," 23.

${ }^{66}$ Goldie, The Mess Inside, 9.
} 
Emplotment is thus the procedure by which a sequence of real or fictional events is represented in narrative form and plot distinguishes representations with narrative form from those without. Both White's discussion and Goldie's description imply that plot is restricted to exemplary narratives, and Harpham's definition follows suit:

The most general and adequate conception of a narrative plot is that it moves from an unstable inaugural condition, a condition that is but ought not - a severance of the two [fact and value] - through a process of sifting and exploration in search of an unknown but retrospectively inevitable condition that is and truly ought-to-be. ${ }^{67}$ A narrative representation is formed by the process of emplotment, emplotment entails movement from the condition of is-but-ought-not-to-be to the condition of is-and-ought-tobe, and narrative form is therefore essentially ethical.

Two necessarily over-simplified examples will serve to illustrate Harpham’s reconceptualisation:

(a) The plot of Downfall moves from Traudl Junge's pride at being selected as one of Hitler's personal secretaries in 1942 (is-but-ought-not-to-be) to her decision to remain loyal in the Führerbunker to the shame she experiences after the war (is-and-ought-to-be).

(b) The plot of Hard Times moves from Thomas Gradgrind's attempts to inculcate relentlessly pragmatic values in the children of Coketown (is-but-ought-not-tobe) to his recognition of the limitations of pure rationalism and thence to his rejection of utilitarian philosophy (is-and-ought-to-be).

The is-and-ought-to-be captures the significance of closure that I emphasised in $\S 1$, which in turn drew on Carroll's statement that a narrative which concludes gives the feeling that it has

${ }^{67}$ Harpham, Shadows of Ethics, 36. 
ceased at precisely the right point, i.e. is retrospectively inevitable in Harpham's terms. Closure contributes to the narrative framework, which determines the standard mode of engagement in the adoption of the internal perspective, and which is itself subject to ethical evaluation in the adoption of the external perspective. The standard mode of engagement with (a) and (b) invites one to view both Traudl and Gradgrind as misguided individuals who - to some extent at least - come to realise the error of their respective ways. As such, both Hirschbiegel and Dickens are subject to positive ethical evaluation from the external perspective.

Although Harpham is critical of Nussbaum for elevating the ethical value of novels to the moral, he makes a similar error. ${ }^{68}$ Here, he identifies a problem in White to which he believes his explanation of narrative form in ethical terms has provided the solution: The difficulty, as one of White's critics has pointed out, lies in the apparent suggestion that there are as many moral orders as there are narratives. But if we define closure in the way I have suggested, we can see that closure achieves a moral order that is "other" to that which preceded it, an other to whatever it is in the narrative that is but ought not to be. There are an infinite number of narratives, but only one closural moral order, which is other not to other narratives but to the incessant questing of all narrative for formal closure. Insofar as our aesthetic education acclimates us to narrative, then, it instructs us in ethics. ${ }^{69}$

Recall from $\S 2$ that White maintains narrative histories are distinguished from non-narrative historical representations (annals and chronicles) by providing an ethical resolution, i.e. the author passes judgement on the sequence of events represented as either moral, immoral, or

\footnotetext{
${ }^{68}$ Harpham, Shadows of Ethics, 220-242.

${ }^{69}$ Harpham, Shadows of Ethics, 43. It is not clear to me that the existence of numerous moral - i.e., ethical in my terms - orders in White is problematic, but my interest here is in Harpham's solution whether or not the problem exists.
} 
morally ambiguous. The criticism mentioned by Harpham is that there are many moral ethical in my terms - orders because White's theory accommodates both Riefenstahl and Hirschbiegel's representations of Hitler as narrative histories. In contrast, Harpham is pursuing a closural moral order and attempting to relate narrativity to moral rather than ethical value.

Harpham has previously made the uncontroversial statement that concern by the self for the other is essential to ethics: 'I see this intimate and dynamic engagement with otherness as the key to the kingdom of ethics: where such an engagement is, there is ethics. ${ }^{70}$ This conception of moral philosophy, popular in the theoretical tradition, is derived from Levinas. ${ }^{71}$ With regard to the ethical turn in criticism, Derek Attridge describes the relevance of Levinas' focus on the other in terms of literature's 'apprehension of otherness', i.e. the capacity of literary works to confront readers with singularity, inventiveness, and alterity. ${ }^{72}$ With regard to narrative representation, Harpham's idea is that the is-and-ought-to-be of closure is other to the is-but-ought-not-to-be with which the plot is inaugurated. In (i) and (ii) above, therefore, the respective plots move from an unstable condition, Junge's pride and Gradgrind's pragmatism, to an inevitable closure, Junge's shame and Gradgrind's rejection of utilitarianism. The conditions of closure are different from - other to - the conditions of inauguration and the process of exploration thus involves a dynamic engagement with otherness and consequently has moral rather than ethical value. As plot, i.e. movement from is-but-ought-not-to-be to is-and-ought-to-be is, is characteristic of all exemplary narratives, Harpham has established the desired link: all narrative representations that are high in

\footnotetext{
${ }^{70}$ Harpham, Shadows of Ethics, $\mathrm{x}$.

${ }^{71}$ See, e.g.: Emmanuel Levinas, Totality and Infinity: An Essay on Exteriority, trans. Alphonso Lingis (Pittsburgh: Duquesne University Press, 1961 [2007]); Ethics and Infinity, trans. Richard A. Cohen (Pittsburgh: Duquesne University Press, 1982).

${ }^{72}$ Derek Attridge The Singularity of Literature (New York: Routledge, 2004), 67.
} 
narrativity exhibit a closural moral order and there is thus a necessary relation between narrativity and moral value.

Concern for the other is indeed ethical and is also usually, but not necessarily, moral. My objection to Harpham is the by now familiar case of narrative representations with negative ethical value, which I shall consider in the terminology he employs. In the respective narratives of Triumph of the Will and The Birth of a Nation the otherness that the standard mode of engagement requires the audience to apprehend involves the acceptance of frameworks which promote the NSDAP and KKK. Levinas is correct in claiming that ethics begins with interest in the well-being of an other instead of - or in addition to - self-interest, but interest in the other is a necessary rather than sufficient condition of moral agency. The plots of both Triumph of the Will and The Birth of a Nation, e.g., are inaugurated with an isbut-ought-not-to-be, explore and apprehend otherness, and close with an is-and-ought-to-be. Neither closural order could, however, be considered moral because the otherness that the standard mode of engagement requires one to assimilate is clearly immoral in both cases. Closural orders are not simply made moral by embracing otherness and - like novels and virtue/vice wheels - can be moral, immoral, or morally ambiguous. The necessary relation expressed in the definition of plot as the movement from is-but-ought-not-to-be to is-andought-to-be is thus between narrativity and ethical value and Harpham's attempt to link narrativity with a closural moral order fails.

Despite my criticism of closural moral order, Harpham's reconceptualisation of narrative form in ethical terms is worth preserving for its illumination of the ethical essence of narrative representation. In $\S 2$, I claimed that the combination of agency and events in narratives entails an ethical dimension to narrative representation the consequence of which is 
that the engagement with a narrative representation qua narrative representation is incomplete without ethical evaluation. I then argued that the ethical dimension is more complex in exemplary narratives, which are essentially ethical in virtue of both the combination of agency and events represented and the agency of the author in adopting the framework particular to the narrative. Harpham's conception of the emplotment characteristic of exemplary narratives as entailing movement from the condition of is-but-ought-not-to-be to the condition of is-and-ought-to-be articulates the necessity of the relationship between exemplary narratives and ethical value without prioritising ethical value above other narrative values (e.g., cognitive value and aesthetic value). The claim that exemplary narratives are essentially ethical is thus restricted to the thesis that they are essentially subject to a dual ethical evaluation. From the internal perspective the actions of the characters, whether real or fictional, may be judged as if they were actual; from the external perspective, the author may be judged for the is-and-ought-to-be with which he or she concludes the narrative; like the actions of the characters, the author's is-and-ought-to-be may be moral, immoral, or morally ambiguous. Finally, the significance of this ethical valence may vary from one exemplary narrative to another. My conclusion is that there is nothing about narrative representation whether exemplary or minimal - that entails moral value, only ethical value. In colloquial terms, every story does indeed have a moral, but that moral may be virtuous, vicious, or somewhere in between. ${ }^{73}$

\footnotetext{
${ }^{73}$ I would like to thank John Gibson, Peter Lamarque, Debbie Roberts, and Jon Robson for their invaluable assistance with this paper.
} 